
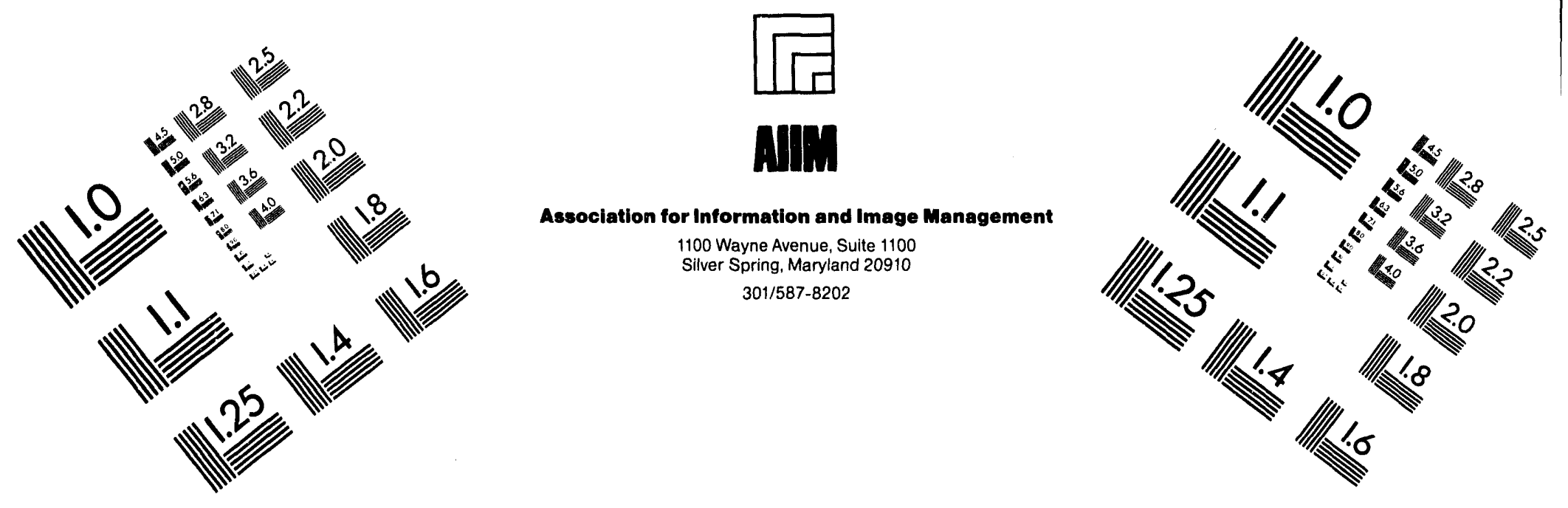

\title{
Centimeter
}

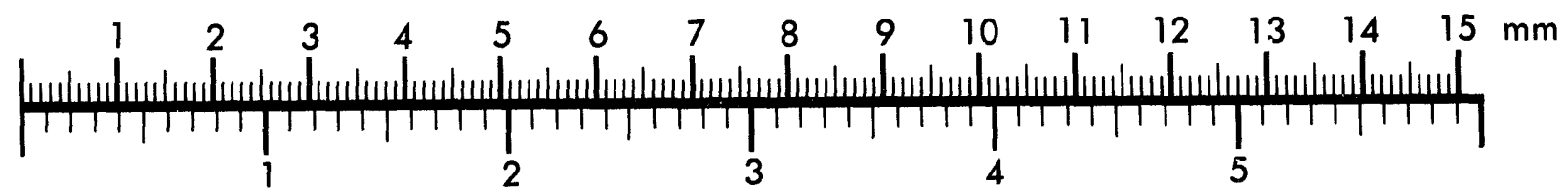
Inches
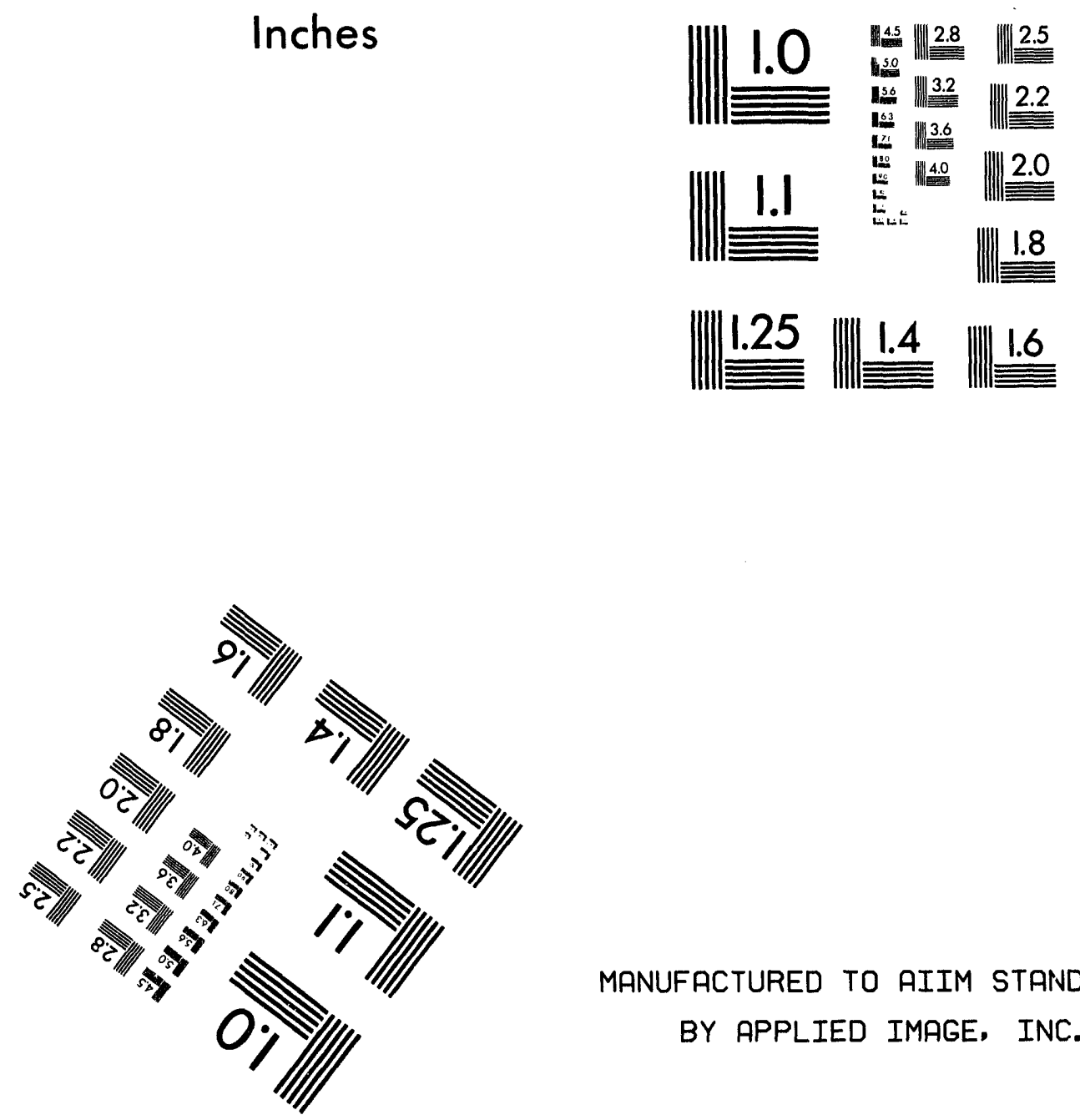

MANUFACTURED TO AIIM STRNDARDS BY APPLIED IMAGE, INC.

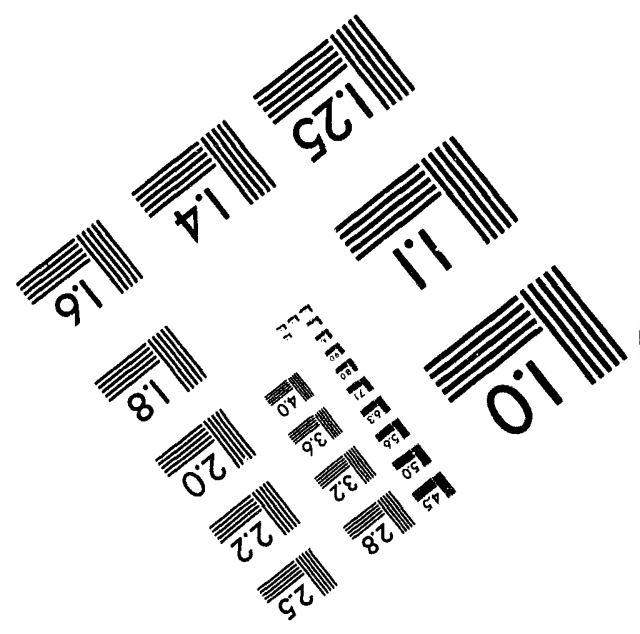



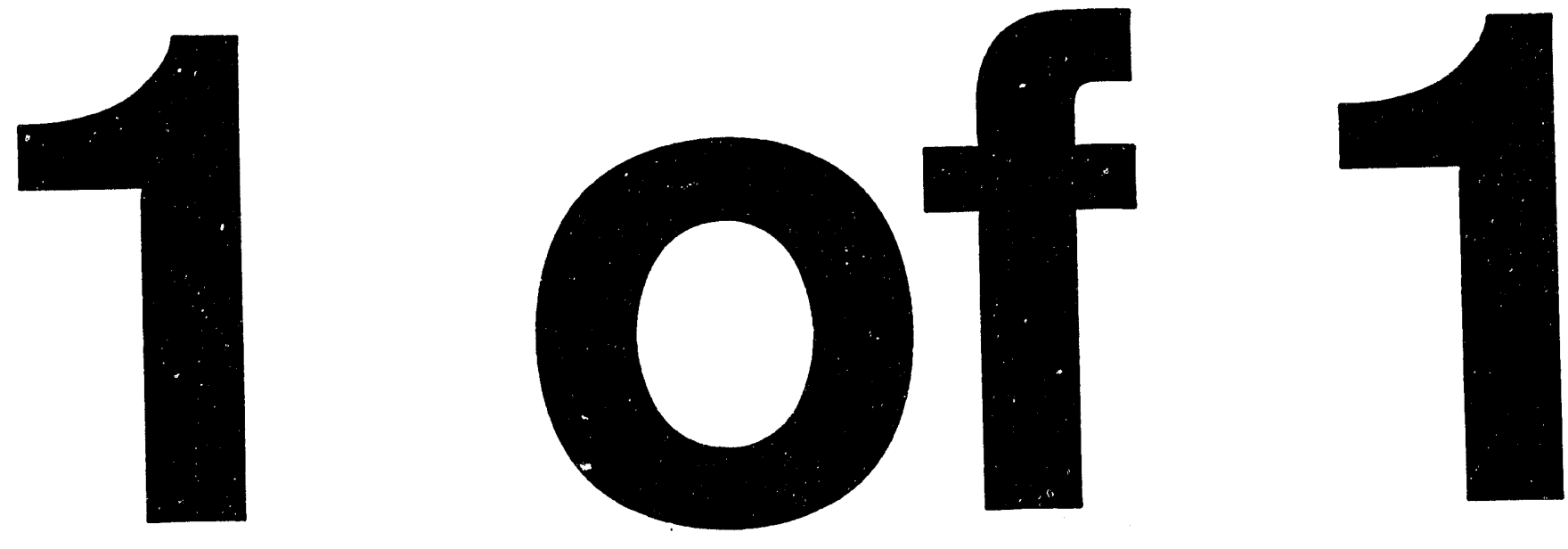

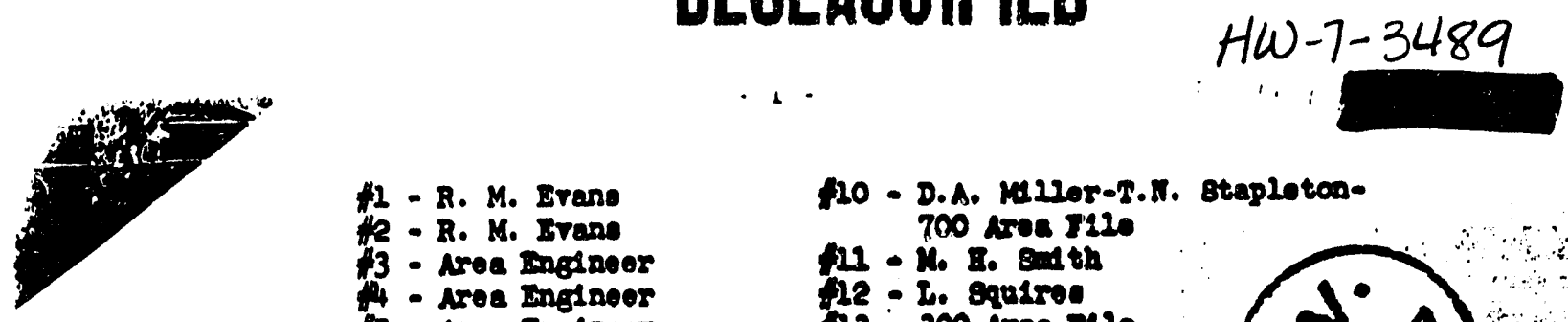

1 - R. M. Erans

HT - R. M. ETane

H3 - Area Inodnoer

4h - Area Inflneer

is - Arra Inolacer

"T6 - Area ingedneer Atto. 8 Patont Croup

(1) - N. InIbersy

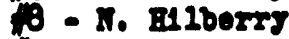

9 - N. BL2boxxy

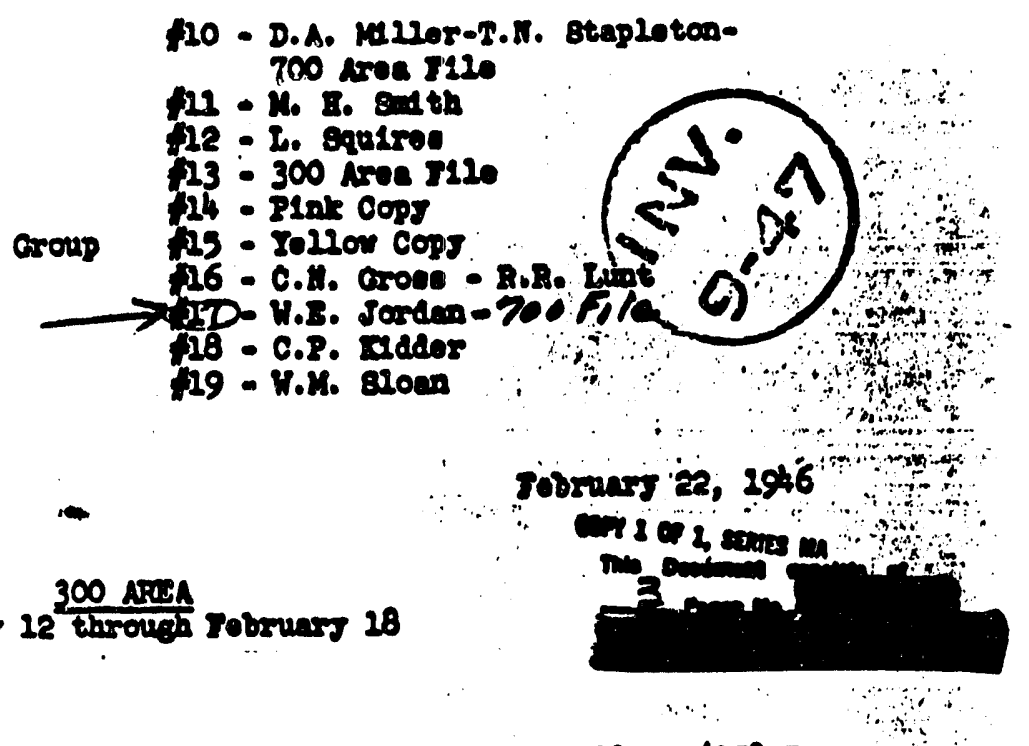

Extruason

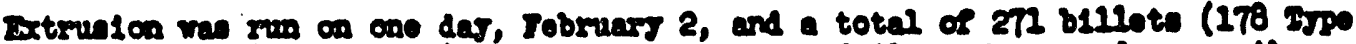
0, 12 typo 8T, and 81 rod band) vero proceosod. Two falluroe boourred among tho rod

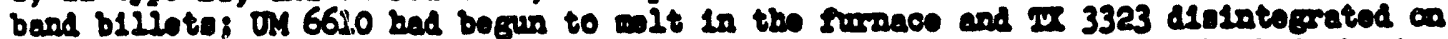

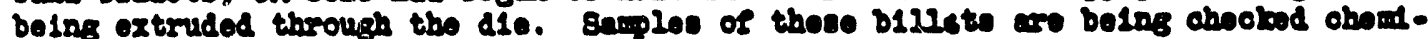
cally and wtaliurgeally in an attompt to ascortaln tho oano for tho hot-lhost characterint10s of thoee bl2loto.

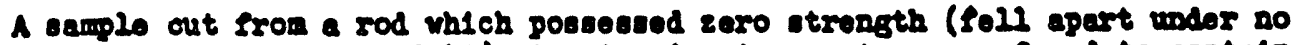

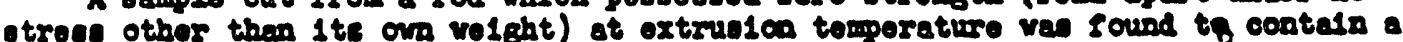

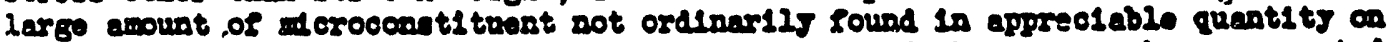

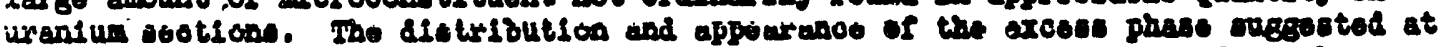

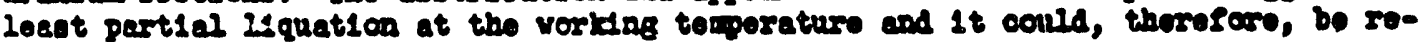
oponasble for the bot-abort tendenoj.

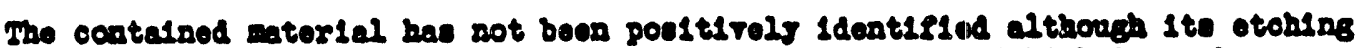

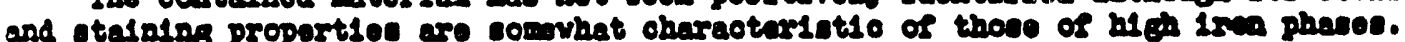

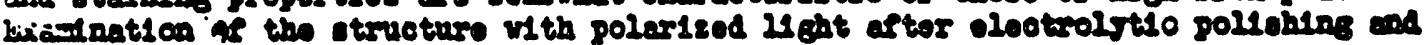

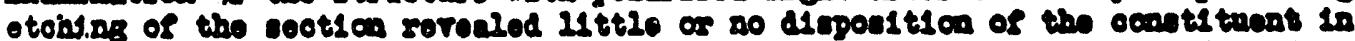

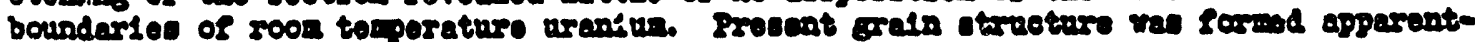
15 unaffectod by the natorlel, althongh the latter appoar laolinch towerd a noto

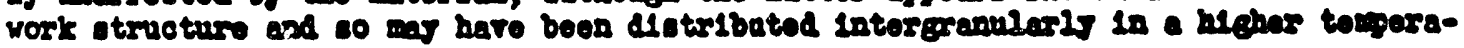
ture modles catton of the uranlus.

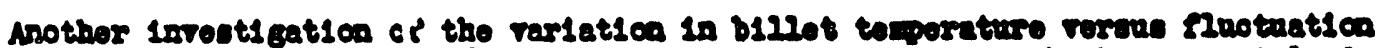

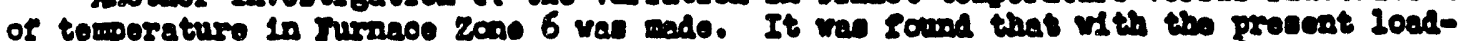

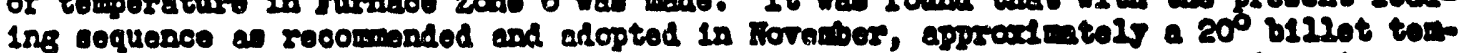

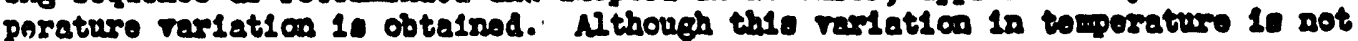

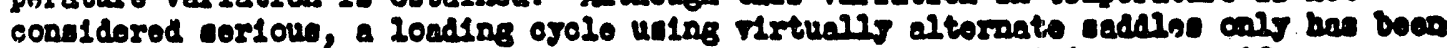

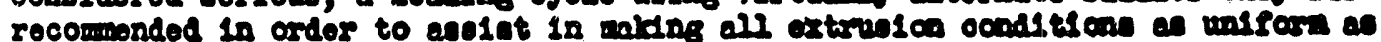
posetble.

\section{Ch1p Recovert}

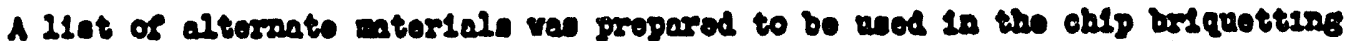

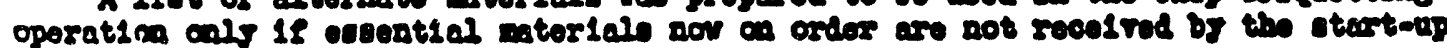
dato. Thece aterlala are as follown

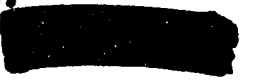

\section{BEST COPY AYALABLE}

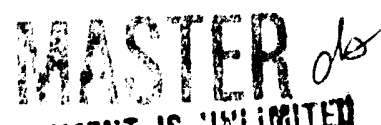

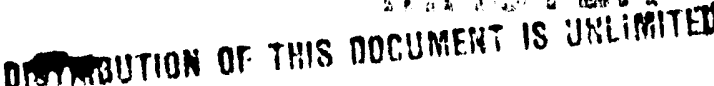




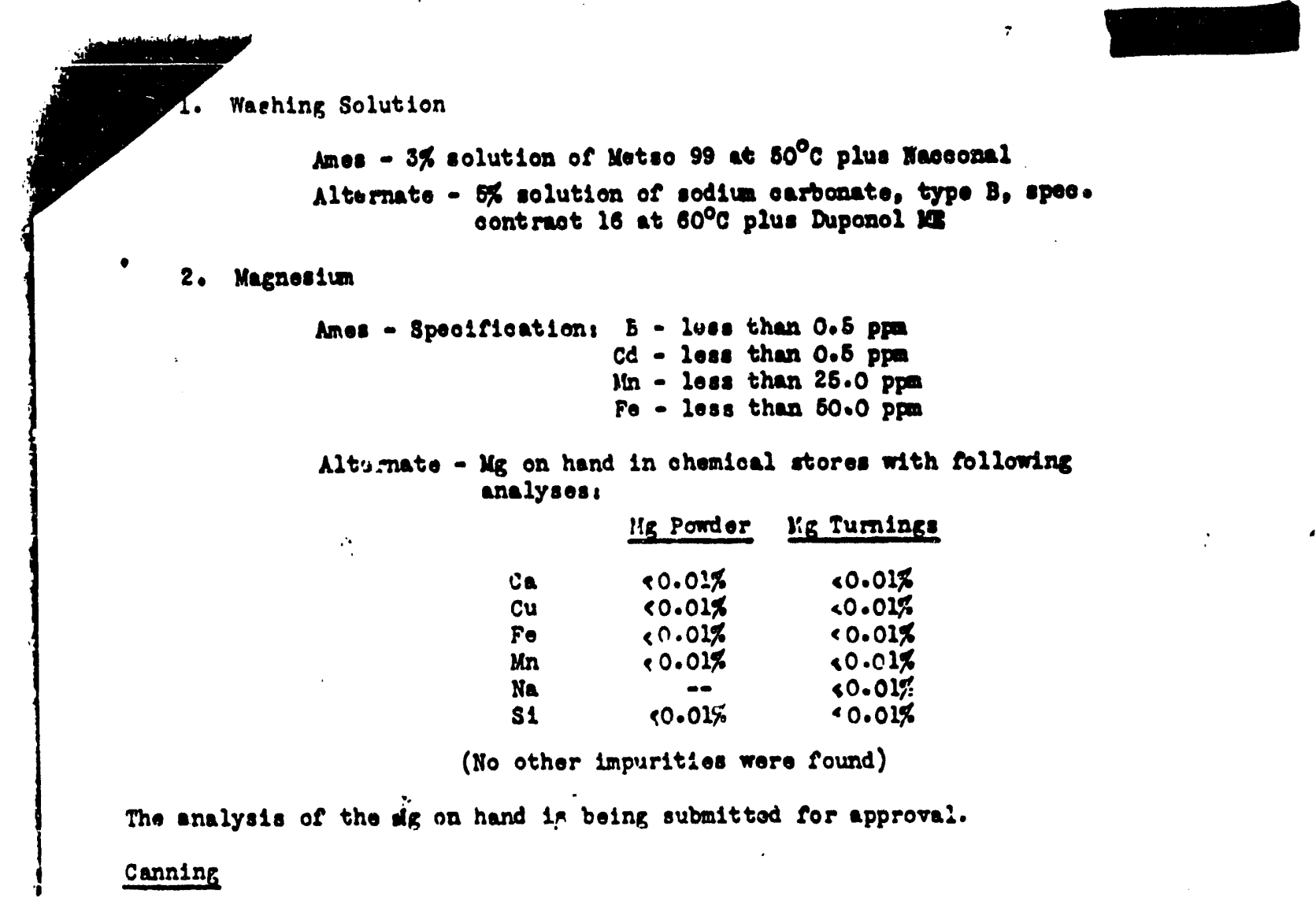

\section{N1tridod S2ooros}

The experinental lot of 473 nit rdded sloeves whioh has beon soounulating during the past several wooks was put into use on Fobruary 18. Contiary to Indications of forror small sosie terts on this type of sloeve, the resulis of the prosent test were unsat lefaotory. The genteral performance of the altrided sleover 1a 1nferlor to that of the normal blued slooves with respect to the tendenoy for $11-81$ to adhere to the sleoves and for warpage of the nlesves to ocour during the quesohing operation. Th1s latter offoot is surprising. In Vow of the fact that the oloeres had been arneeled at a tenperature in exoess of $1100^{\circ} \mathrm{F}$ for orer an hour and $1 t$ was sxpeoted that all Internal stresses should hare been thoroughly rolleved during

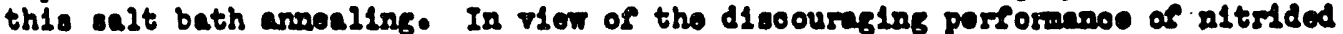
sleores, the study of nit rided leores 111 be dieoontimed. It is howerer, bee

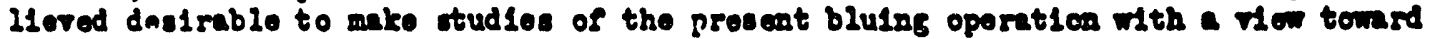
ostablisining temperature 11mits and hesting time IInlte for this operation so that unlform resulte may bo obtained.

\section{Produotion Tout 313-75-K (Selooted Slugs)}

The proparation of opeolally seleoted materind for thl tort has bece ocmploted and the oanned pleoes are now in prooese of inspeotion. After belng autoolared and eraluated in the Toot P110, they w1I be ehlpped on Keroh 5 to 100-B Area for exposure.

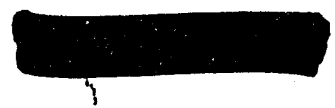




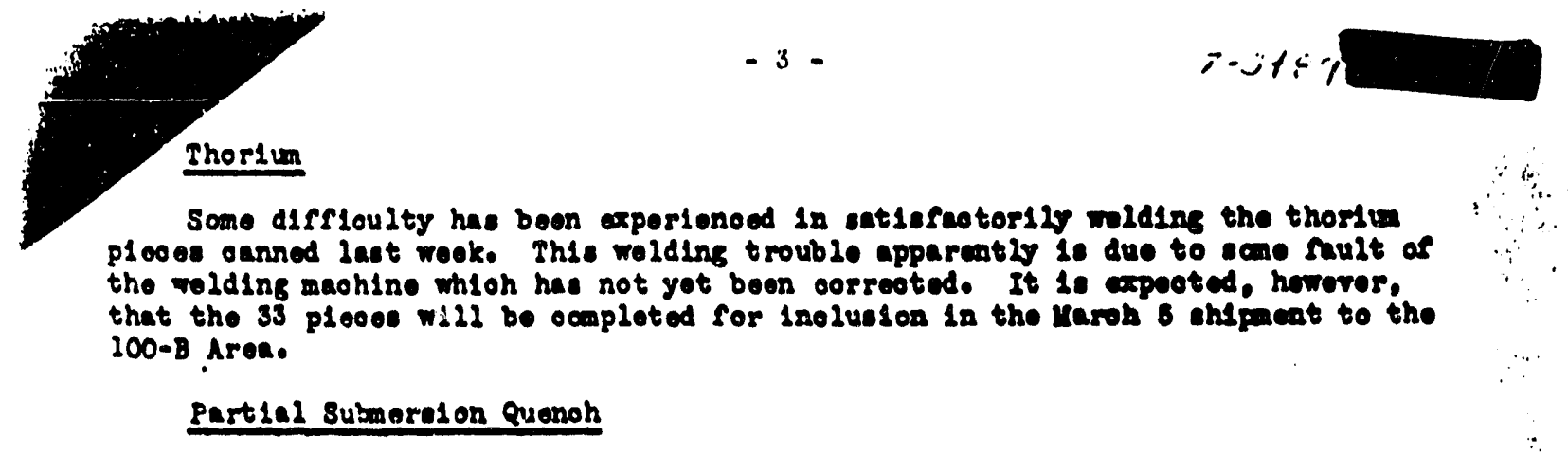

It has been efreed that the partiel submersion quenoh proedure w12 be adopted

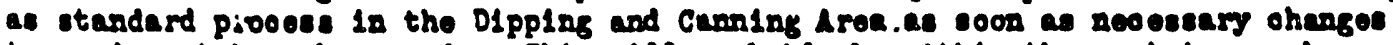
to equipment have boen aede. Thle will probably be withle the next two woeke.

\section{Canning Math Compostion ve minklod Cane}

During the latter part of the enift of Pobruary 16 an exoessite muber of wrinkled oane frem pot $3 C_{2}$ mas not od and a samplo of the bath abbitted to the laboratory for otudy. Thermal analysin of tho sanple indloated a 81 oont ent of

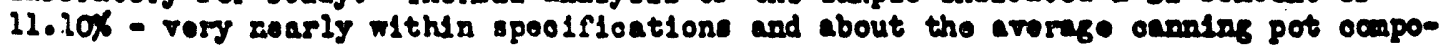
sitlon noar the olose of the shift. Study of pollshod seotlons of apecinens onet from the cuple rovealed a large anount of urantu, largoly an asfregaten. This has been noted provlously and not nocesser1ly 12 conjunotion with tho appearanoe of wrinkled ones. Hence, peadling Nurther study; some faotor other then bath composit10n must bo asmened to hro boen at rault:

It has beon roquested that sanples from both the brones pot and canning pot

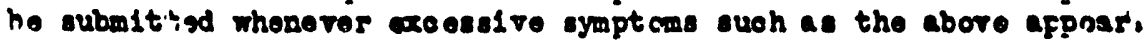

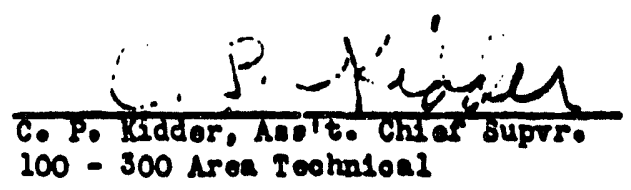

CPKigd 

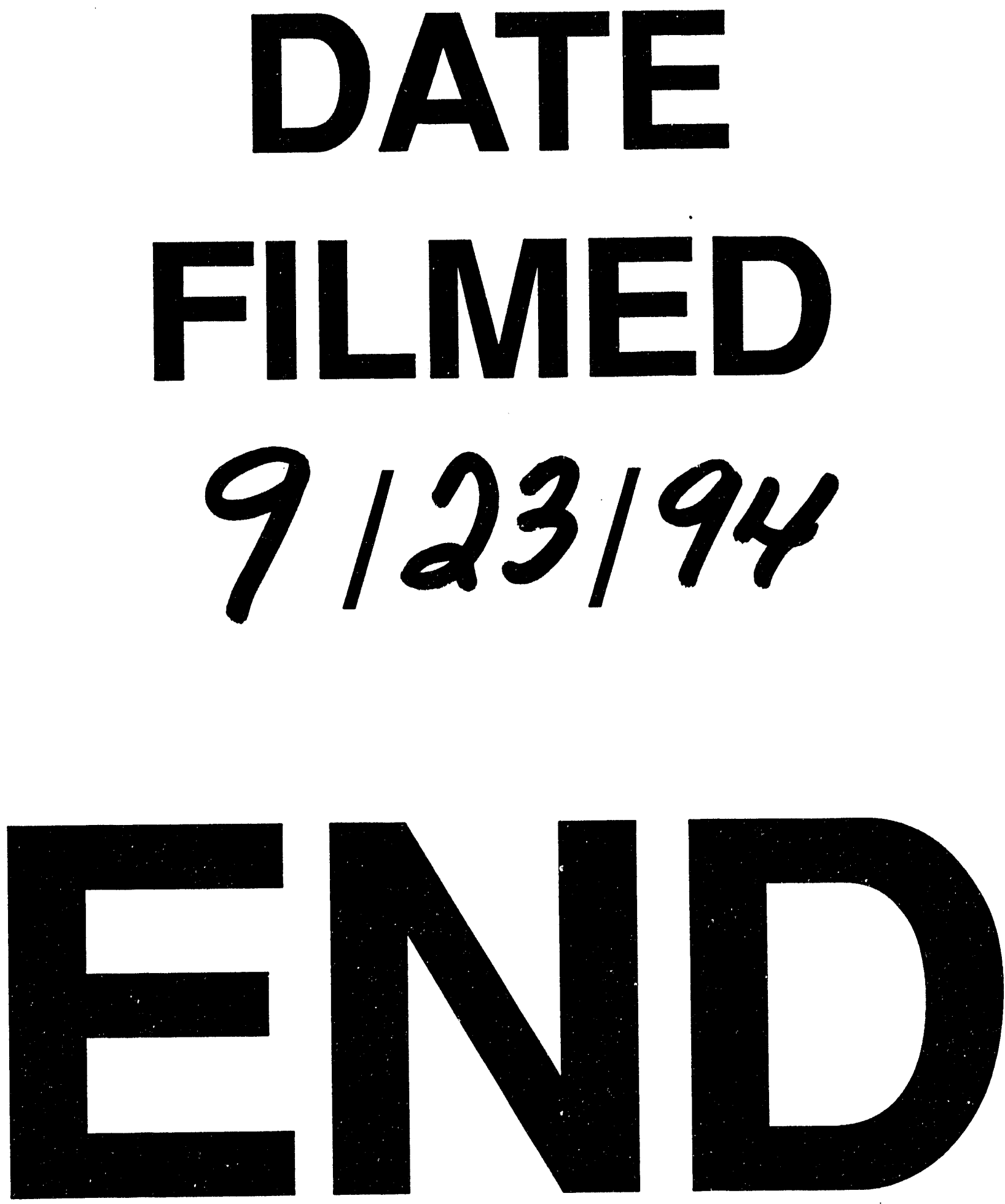
